\title{
Problem poprawy
} efektywności organizacji poprzez mobilizację potencjału ludzi z perspektywy literatury zarządzania wiedzą i psychologii

\author{
Dr Piotr Kaczmarek-Kurczak | Akademia Leona Koźmińskiego, Warszawa \\ | pkurczak@kozminski.edu.pl \\ Dr Magdalena Kaczmarek | Szkoła Wyższa Psychologii Społecznej, Warszawa \\ | magda.kaczmarek@swps.edu.pl
}

\section{Abstrakt}

\section{Cel}

Celem niniejszego artykułu jest zaprezentowanie aktualnych tendencji w literaturze zarządzania wiedzą i zarządzania zasobami ludzkimi dotyczącej roli personelu w zwiększaniu skuteczności działania organizacji. W oparciu o podejście zasobowe (RBV) (Barney 1991) zachodzi w ostatnich latach szybkie zbliżenie pomiędzy dwoma kierunkami, zwłaszcza w sprawie roli odgrywanej przez cechy osobiste, charakterystyki poznawcze i zaangażowanie pracowników w podnoszenie efektywności i poprawę pozycji rynkowej firm. 


\section{Metodologia/wyniki}

Omawiając literaturę, niniejszy tekst wskazuje obecne tendencje w badaniach nad mobilizacją potencjału pracowników i ewentualne kierunki rozwoju dyscyplin zarówno nauk o zarządzaniu, jak i psychologii. W artykule omawiamy również płaszczyznę dalszego schodzenia się zainteresowań obu kierunków badawczych w kwestii roli systemów motywacyjnych, szkoleniowych i społecznych w budowaniu strategii przedsiębiorstwa - czyli w domenie strategicznego zarządzania zasobami ludzkimi (SHRM).

\section{Oryginalność}

Zadania stojące przed współczesnymi systemami HR są znacznie bardziej ambitne niż przy klasycznie rozumianym HR i skupiają się raczej na rozwiązywaniu czterech głównych problemów: 1) jak wykorzystać wewnętrzny potencjał pracowników do reagowania na zmiany i dokonywania innowacji? 2) jak zwiększać ten potencjał? 3) jak wykorzystać procesy grupowe w rozwiązywaniu problemów organizacyjnych? 4) jak wprząc kapitał ludzki i kapitał społeczny firmy w realizację strategicznych celów przedsiębiorstwa, a zwłaszcza jak przekuć ten potencjał w pozycję rynkową i finansową stabilność? Odpowiedzą na to wyzwanie może być omawiany nurt SHRM.

Słowa kluczowe: strategiczne zarządzanie zasobami ludzkimi (SHRM), zarządzanie wiedzą, podejście oparte na zasobach (RBV)

\section{JEL : M51 \\ Wprowadzenie}

Od połowy XX w. w nauce zarządzania zachodzą bardzo szybkie zmiany w podejściu do roli i sposobów wykorzystania zasobów ludzkich w organizacji. Widać wyraźnie rozwijającą się tendencję do poszukiwania metod coraz bardziej intensywnego i wielowymiarowego wykorzystania możliwości pracowników. Jeśli można bowiem jakoś określić drogę, jaką pokonało zarządzanie od czasów Taylora do dnia dzisiejszego, to chyba jako „odkrywanie potencjału człowieka” (Birdi et al. 2008).

Klasyczny model naukowego zarządzania był oparty na prostej, ale rewolucyjnej w tym czasie idei klonowania ludzkich umiejętności (Drucker 1999). Specjaliści obserwowali czynności wykonywane przez najlepszych pracowników, tworzyli na ich podstawie optymalną procedurę wykonywania danej pracy, którą następnie wdrażano w całej firmie, szkoląc do jej wykonywania pozostałych wykonawców (Drucker 1999). Nad dokładnością i starannością wykonywania procedur czuwały zastępy nadzorców ze stoperami w rękach. Dzięki temu możliwe było szybkie podnoszenie efektywności pracy rzesz niewykwalifikowanych pracowników - cecha, dzięki której USA były w stanie wygrać wojnę (Drucker 1999). W tym podejściu w zasadzie wiedza w dzi- 
siejszym rozumieniu koncentrowała się jedynie na średnich i wyższych szczeblach zarządzania. Mimo że pracownicy wykonywali daną czynność, nie musieli ani jej rozumieć, ani wiedzieć, na czym polega i jak ją zmodyfikować. Inteligencja była potrzebna pracownikom w zasadzie tylko na pierwszym etapie przyswajania nowej procedury. Potem na pierwszy plan wysuwały się wytrzymałość fizyczna i odporność (w tym odporność na stres i nudę).

Kierunek Human Relations nie wniósł do tego obrazu zbyt wiele, zastępując jedynie motywację zewnętrzną - chęć zdobycia nagrody lub uniknięcia kary za zbyt wolne lub niedokładne wykonywanie procedur - motywacją wewnętrzną, płynącą z indywidualnych potrzeb. Dzięki wewnętrznej motywacji pracownicy byli bardziej odporni na wpływ warunków fizycznych i lepiej radzili sobie ze stresem (Mayo 1933).

Dopiero w II połowie XX w. model taylorowski przestał wystarczać (Drucker 1999). Wiązało się to z dwoma zjawiskami. Pierwszym z nich były przemiany otoczenia organizacji, które w wyniku rosnącego dobrobytu, zmian technologicznych, wychodzenia firm w środowisko międzynarodowe i rosnącej integracji ekonomicznej różnych regionów świata stawało się coraz bardziej burzliwe i zmienne. Drugim był rozwój technologii informatycznych i automatyzacji, który pozwolił olbrzymią część zadań dotychczas wykonywanych przez ludzi przerzucić na maszyny. W świecie efektywnych automatów sprawność wykonywania powtarzalnych czynności przestała być kluczową przewagą organizacji (Drucker 1999).

W konsekwencji pojawiła się konieczność zwiększenia elastyczności działania firm i ich adaptacyjności (Drucker 2004). Oznaczało to konieczność odejścia od taylorowskiego modelu organizacji, w którym zwiększanie efektywności organizacji następowało poprzez stopniowe udoskonalanie procedur działania, a następnie rozpowszechnianie ich i wprowadzanie ścisłej kontroli ich wykonywania przez pracowników. Pojawiła się coraz wyraźniej widoczna konieczność oddawania inicjatywy w ręce pośrednich i niższych szczebli zarządzania (Drucker, 1999), a zwłaszcza zwiększania innowacyjności w dopasowaniu procedur do szybko zmieniających się oczekiwań i potrzeb klientów. Oznaczało to wzrost znaczenia dotychczas ignorowanych czynników, jakimi były:

- zdolności poznawcze pracowników, a szczególnie zdolność rozumienia istoty wykonywanej przez nich pracy i wprowadzania w niej modyfikacji zwiększających skuteczność działania,

- cechy psychiczne i osobowościowe personelu, wpływające na jego zdolność rozwoju osobistego, współdziałania w grupie i radzenia sobie z nowymi wyzwaniami. W konsekwencji coraz silniej narastało wśród praktyków i teoretyków przekonanie, że przyszłość nowoczesnych organizacji zależeć będzie od znalezienia skutecznych sposobów zwiększania wykorzystania tych niewykorzystanych do tej pory elementów potencjału pracowników (Birdi et al. 2008; Becton, Schraeder 2009). 


\section{| Od zarządzania wiedzą do SHRM}

Mimo że koncepcja „społeczeństwa wiedzy” pojawiała się w literaturze wielokrotnie (Jakubik 2007), jednym z pierwszych przejawów nowego spojrzenia na rolę zasobów ludzkich w organizacji było pojawienie się na początku lat 90. (w pewnym sensie na fali euforii po wygranej dzięki „inteligentnym broniom” pierwszej wojnie w Zatoce Perskiej) w popularnych pismach biznesowych artykułów poświęconych roli wiedzy/inteligencji jako kluczowego czynnika dającego przewagę krajom Zachodu w nowoczesnym świecie (Stewart 1991), czemu zaczął towarzyszyć systematyczny wzrost zainteresowania tą problematyką ze strony praktyków, a potem naukowców (Serenko et al. 2010). Pojawiły się pozycje popularyzujące koncepcje „organizacji produkujących wiedzę” (Nonaka 1994; Nonaka, Takeushi 2000) i „organizacji inteligentnej” (Senge 1998). Co interesujące - wśród autorów publikacji na temat zarządzania wiedzą początkowo dominowali praktycy i dopiero po 1995 r. zarządzanie wiedzą zaczęło się szybko rozwijać jako domena zainteresowania naukowców. W szczytowym dla tej tendencji 1997 r. udział autorów-praktyków w publikacjach na temat ZW wynosił 48,3\% i dopiero od tego momentu zaczął systematycznie spadać, osiągając dzisiejszy poziom 10\% (Serenko, Bontis, Booker, \& Sadeddin, 2010). Był to okres, w którym wykorzystanie nawet stosunkowo prostych rozwiązań, takich jak mapy wiedzy lub bazy danych stworzonych już rozwiązań, mogło przynieść organizacjom dość wyraźną przewagę w stosunku do konkurentów (Davenport, Prusak 1998). Ankiety przeprowadzone na początku XXI w. wśród dyrektorów naczelnych (CEO) firm amerykańskich wskazywały, że uznawali oni wprowadzenie systemów zarządzania wiedzą za najistotniejszą zmianę, jaka zaszła w środowisku biznesowym, ustępującą pod względem znaczenia jedynie globalizacji (Grossman 2006). Dlatego firmy intensywnie eksperymentowały z różnymi rodzajami systemów zarządzania wiedzą - skupiając się przede wszystkim na wykorzystaniu technologii informatycznych w poprawie efektywności wykorzystania wiedzy (Hendricks 2001). Wiedza postrzegana była w sposób statyczny (Jakubik 2007: 12), jako jeden z kluczowych zasobów przedsiębiorstwa, jednak w pewnym oderwaniu od kwestii wytwórców wiedzy. To izolowanie wiedzy od jej nosicieli ułatwiało „skolonizowanie” nowej dyscypliny przez przedstawicieli kierunków informatycznych (Hendricks 2001; Jakubik 2007).

Na początku XXI w. już ponad 81\% czołowych firm europejskich i amerykańskich zdążyło wdrożyć u siebie jakieś odmiany systemów zarządzania wiedzą (Grossman 2006). Mniej lub bardziej zaawansowane systemy zarządzania wiedzą zbudowały wtedy u siebie m.in. Accenture, Cable \& Wireless, DaimlerChrysler, Ernst \& Young, Ford, Hewlett Packard, Unilever (Grossman 2006). Ceny technologii informatycznych używanych w systemach ZW drastycznie spadły (np. dzięki rozpowszechnieniu rozwiązań internetowych), co przyspieszyło ich upowszechnienie, a proste systemy ZW nie dawały już tak wyraźnej przewagi wobec konkurencji, jak w latach 90. Dopiero kiedy najważniejsze koncepcje i narzędzia zarządzania zasobami wiedzy bardzo się upowszechniły, przedstawiciele biznesu i nauki zaczęli zwracać baczniejszą uwagę na procesy i kontekst tworzenia wiedzy w przedsiębiorstwie. Uwaga przesunęła się „,z obiektu na twórcę” (Jakubik 2007: 17) - zainteresowanie środowiska praktyków przesunęło się z systemów zarządzania wiedzą w stronę problemu zarządzania kapitałem ludzkim (Thompson et al. 2001), ze szczególnym 
uwzględnieniem problemu zharmonizowania rozwoju potencjału pracowników z realizacją strategicznych celów przedsiębiorstwa (Wright et al. 1999).

W pewnym sensie wczesna forma zarządzania wiedzą pasowała do biurokratycznego schematu działania HR. Strategia kodyfikacji wiedzy (Jakubik 2007): tworzenie narzędzi informatycznych ułatwiających gromadzenie informacji, zarządzanie szkoleniami personelu itp. dobrze odpowiadały możliwościom i praktykom działania HR. Od czasów Fayola HR postrzegany był jako jeden z działów funkcjonalnych, wykonawczych względem biznesowych koncepcji rozwoju przedsiębiorstwa tworzonych przez zarządzających. Ludzie byli dobierani do zadań stojących przed organizacją, stanowili wymienny element struktury stworzonej do realizacji długoterminowych celów postawionych przez właścicieli i decydentów.

Usługowe rozumienie roli działów HR bardzo trudno jest zmienić, nie tylko ze względu na opór ze strony zarządzających firmami, którzy dopiero od niedawna zaczęli postrzegać personel jako coś więcej niż tylko tryby w maszynie, ale również ze względu na nastawienie samych przedstawicieli HR, którzy rzadko formułują szersze plany rozwoju kapitału ludzkiego swoich organizacji. W 1998 r. w ankiecie przeprowadzonej wśród 1050 firm amerykańskich menedżerowie zadeklarowali, że tylko 1/3 swojego czasu poświęcają na działania związane z opracowaniem koncepcji rozwoju personelu. Resztę czasu pochłaniały im biurokratyczne czynności związane z obsługą formalną zatrudnionych pracowników. Wyniki ankiety przeprowadzonej w 2006 r. przez Stowarzyszenie Zarządzania Zasobami Ludzkimi (Society for Human Resources Management) wykazały, że tylko 56\% respondentów w ankietowanych przedsiębiorstwach deklaruje, że ich organizacje mają plan rozwoju umiejętności i kompetencji pracowników (Becton, Schraeder 2009).

Wsparciem dla zmian w podejściu do HR jest powrót w zarządzaniu wiedzą do koncepcji tzw. personalizacji wiedzy, która traktuje wiedzę organizacyjną jako rezultat interakcji pracowników z systemem zarządzania organizacji (Jakubik 2007). Początkowe zainteresowanie podejściem systemowym do zarządzania wiedzą i umiejętnościami, które rozwijało się w połowie lat 90 ., zostało szybko zdominowane przez rozwiązania zasobowe oparte na narzędziach IT ułatwiających gromadzenie i dzielenie się informacjami.

\section{"Ukryta potęga": osobowość, zaangażowanie, wiedza, zbiorowość}

Dzisiejsze środowisko biznesu stawia o wiele większe wymagania przed organizacjami. Oznacza to, że konieczne są nowe podejścia i techniki do zarządzania personelem. Współczesne organizacje w ograniczonym stopniu są w stanie przewidzieć, jakie zmiany będą zachodziły na rynku i jakim wyzwaniom będą musiały podołać. Zmuszone są do improwizacji, a w konsekwencji do opierania się nie tyle na wypracowanych wcześniej procedurach działania, ile na zdolności swoich pracowników do postępowania we właściwy sposób w nowych okolicznościach (Becton, Schraeder 2009: 11-12). 
W związku z tym zmieniają się wyzwania stojące przed systemem HR. Klasyczny HR koncentruje swoje działania przede wszystkim na pozyskiwaniu pracowników z otoczenia i zarządzaniu ich więziami formalnymi z przedsiębiorstwem. Nie jest traktowany jako część systemu bezpośredniego zarządzania - na ogół jedynie służy wsparciem w kwestiach formalnych kierownikom liniowym. Zadania stojące przed współczesnymi systemami HR są znacznie bardziej ambitne i skupiają się raczej na rozwiązywaniu czterech głównych problemów:

1) jak wykorzystać wewnętrzny potencjał pracowników do reagowania na zmiany i dokonywania innowacji?

2) jak zwiększać ten potencjał?

3) jak wykorzystać procesy grupowe w rozwiązywaniu problemów organizacyjnych?

4) jak wprząc kapitał ludzki i kapitał społeczny firmy w realizację strategicznych celów przedsiębiorstwa, a zwłaszcza jak przekuć ten potencjał w pozycję rynkową i finansową stabilność?

W chwili obecnej nie ma zgody wśród badaczy co do jakiegoś uniwersalnego schematu pozwalającego podnosić efektywność działania organizacji w przyszłości. Z analizy literatury można jednak wyciągnąć interesujące wnioski dotyczące potencjalnych kierunków poszukiwań.

Pierwszym z nich jest niewątpliwie szersze włączanie pracowników w procesy decyzyjne przedsiębiorstwa i dalsze eksperymenty z różnymi formami zarządzania partycypacyjnego. Mimo złej opinii, jaką zarządzanie partycypacyjne zyskało wśród praktyków, zwłaszcza w Polsce, nie ma wątpliwości, że tendencja oddawania w ręce pracowników coraz większej autonomii i wykorzystywania ich umiejętności do rozwiązywania problemów na różnych poziomach organizacji będzie kontynuowana. Badania (Ferguson, Reio 2010; Markos 2010) wskazują, że istnieją silne powiązania pomiędzy inwestycjami w rozwój osobisty pracowników, inwestycjami w partycypacyjne systemy zarządzania procesami organizacyjnymi a efektywnością i produktywnością organizacji. Samozarządzające sobą grupy robocze oraz intensywne szkolenia i treningi, wraz z partycypacją w wynikach finansowych przedsiębiorstwa oraz względną stabilnością zatrudnienia, są istotnie powiązane z produktywnością średniej wielkości firm amerykańskich (Hassan et al. 2006). Dane zebrane w trzech turach w latach 1996-2003 w brytyjskich firmach produkcyjnych pokazały, że spośród wprowadzonych w tych firmach praktyk zarządzania to właśnie empowerment i szkolenia podnoszące rozumienie procesów organizacyjnych i technologii przyniosły największe i najbardziej długofalowe skutki dla produktywności przedsiębiorstw (Birdi et al. 2008). W firmach, które wprowadziły u siebie zarządzanie partycypacyjne i dały pracownikom dużą autonomię w konfigurowaniu procesów pracy, wartość dodana na pracownika wzrosła w zbadanym okresie o prawie 7\% (przy zachowaniu silnej statystycznej istotności uzyskanych wyników), w firmach wdrażających intensywne programy szkoleniowe i mentoringowe - o ponad 6\% (Birdi et al. 2008). W firmach, które wdrożyły u siebie oba rozwiązania, połączony efekt obu metod przyniósł 9\% wzrost wartości dodanej na pracownika (Birdi et al. 2008). Co ciekawe, podniesienie efektywności produkcji nastąpiło w dość krótkim czasie: w przypadku wprowadzenia elementów zarządzania partycypacyjnego efekt w postaci wzrostu produktywności 
ujawnił się w okresie od 1 do 4 lat (Birdi et al. 2008). Praca zespołowa nie miała tak wyraźnego powiązania z produktywnością, o ile była traktowana jako niezależna praktyka organizacyjna. Jednak połączona z decentralizacją i partycypacją pracowników w procesach zarządzania oraz z intensywnymi procesami szkolenia również podnosiła poziom produktywności, działając jak dodatkowy stymulator (Birdi et al. 2008).

Drugim kierunkiem potencjalnych poszukiwań jest kontynuowanie wyznaczonego przez zarządzanie wiedzą wykorzystywania wiedzy i umiejętności jako jednego z unikalnych i trudnych do podrobienia zasobów, na których zbudowana może zostać przewaga konkurencyjna firmy. Obecnie badacze związani zarówno z kierunkiem HR, jak i KM zaczynają łączyć swoje siły, analizując, w jaki sposób wykorzystanie wiedzy w przedsiębiorstwie zostaje aktywowane poprzez systemy zarządzania zasobami ludzkimi przedsiębiorstwa (Jakubik 2007: 17). Wspólne analizy są możliwe właśnie ze względu na wykorzystanie w obu kierunkach jako metodologicznej podstawy do analiz modeli opartych na podejściu zasobowym (Resources Based View - RBV; Birdi et al. 2008). Podejście oparte na zasobach (RBV) wzbudza zainteresowanie uczonych zajmujących się strategicznym wymiarem zarządzania zasobami ludzkimi i zarządzaniem wiedzą przede wszystkim dlatego, że pozwala ując pracę ludzi i ich wiedzę we wspólnym systemie wraz z kapitałem finansowym, rzeczowym, społecznym, symbolicznym itp., umożliwiając integralne planowanie działań (Chadwick, Dabu 2009). RBV kładzie nacisk na wykorzystanie wewnętrznych źródeł przewagi konkurencyjnej firmy i pozwala rozbudować je o kolejne elementy, chociażby takie, które dotyczą sposobów organizacji pracy, projektowania zadań, kształtowania relacji pomiędzy pracownikami itp. (Chadwick, Dabu 2009), w czym zainteresowania HRM zbiegają się bardzo ściśle z zainteresowaniami zarządzania wiedzą (Jakubik 2007). Szczególnie wpływowe okazały się prace Barneya (1991) oparte właśnie na podejściu RBV, w których zaproponowano pojęcia wartości, rzadkości, niepodrabialności i niezastępowalności (Value-Rarity-Inimitability-Non-substitutability - VRIN) jako kryterium oceny, czy dane zasoby mogą tworzyć trwałą przewagę konkurencyjną (Bamberger, Meshoulam, 2000). Liczni przedstawiciele podejścia strategicznego do HRM sugerowali w swoich pracach, że zasoby ludzkie spełniają właściwości VRIN (Chadwick, Dabu 2009) i rzeczywiście, trzeba przyznać, że większość badań poświęconych strategicznemu HRM odwołuje się do podejścia zasobowego (Chadwick, Dabu 2009). Podobnie dzieje się zresztą w zarządzaniu wiedzą (tzw. commodity view, ale również część tzw. podejścia społecznościowego, czyli community view) (Jakubik 2007). Niestety - podzielając zainteresowanie RBV, oba kierunki są narażone również na jego słabości. W ogromnej większości przypadków odwołanie do koncepcji RBV służy bowiem jedynie jako uzasadnienie dla prowadzonych według różnych podejść badań, natomiast nie stanowi źródła nowych, testowalnych hipotez (Barney 2001). Jak zauważył jeden z badaczy tego kierunku: „Samo stwierdzenie, że trudne do naśladowania zasoby są niezbędne do zbudowania przewagi konkurencyjnej i że w tym sensie zasoby ludzkie są szczególnie cenne, nie zaprowadzi nas zbyt daleko" (cyt. za Chadwick, Dabu 2009: 254).

W kontekście zarządzania wiedzą wspólne zainteresowanie koncepcją unikalnych zasobów wiedzy tworzących przewagę konkurencyjną firmy nie wyczerpuje możliwości działania. Pozostając w tym samym paradygmacie RBV, zwolennicy podejścia opartego na personalizacji wiedzy 
(podejście społecznościowe - community view) zwracają się ku budowaniu unikalnych relacji pomiędzy pracownikami, które spełniać mają wymagania koncepcji VRIN, a których efektem jest zarówno innowacyjność działania firmy, jak i nowe produkty oraz wiedza.

Rozwijanie wiedzy pracowników poprzez pobudzanie ich kreatywności i zdolności społecznych jest uważane za jeden z najbardziej obiecujących kierunków rozwoju w zarządzaniu wiedzą (Becton, Schraeder 2009; Sun 2010; Carleton 2011). Interesujące wydają się również eksperymenty z tworzeniem i wykorzystaniem systemów IT służących zarządzaniu relacjami pomiędzy kompetencjami pracowników (drzewa kompetencji organizacyjnych) (McHenry, Strřnen 2008). Narzędzia informatyczne wykorzystywane są również do budowania sieci społecznych, a zwłaszcza wykorzystywane w próbach budowania w organizacjach systemów inteligencji zbiorowej, opartych na doświadczeniach wyniesionych z Internetu (Razmerita et al. 2009), oraz najnowszych odkryć psychologicznych dotyczących mechanizmów ujawniania się zbiorowej inteligencji w działaniach małych grup postawionych wobec trudnych zadań (Woolley et al. 2010).

\section{Wiedza o zachowaniu człowieka a praktyki HR}

Zmieniające się praktyki zarządzania kapitałem ludzkim oraz rosnąca rola zarządzania wiedzą w organizacji skłaniają ku bardziej podmiotowemu postrzeganiu pracowników, do tego, aby w większym stopniu uwzględniać ich indywidualne potrzeby oraz uzdolnienia. Pociąga to z kolei za sobą większą niż wcześniej konieczność zastosowania w praktyce wiedzy płynącej z badań psychologicznych. Rola psychologii jest więc rosnąca, gdyż uwzględnienie wiedzy o prawidłowościach zachowania człowieka w działaniach HR prowadzi do zwiększenia zaangażowania pracowników, a także zwiększenia innowacyjności na poziomie poszczególnych ludzi oraz zespołów. Praktyczne zastosowanie psychologii może także pomóc w przeciwstawianiu się patologicznym zachowaniom w organizacji, takim jak wypalenie zawodowe czy przejawy nielojalności czy nieuczciwości pracowników (por. Bartkowiak 2010).

Analizując literaturę z zakresu HR, można zauważyć, że modele i pojęcia, którymi się dość powszechnie posługują autorzy prac z tej dziedziny, z punktu widzenia psychologii mają niejednokrotnie bardziej historyczny charakter. Przykładem może być jest pojęcie i model motywacji. W podręcznikach HR podkreśla się rolę potrzeb, przeciwstawiając je popędom, wskazuje się na hierarchię potrzeb i zaznacza, że obok potrzeb braku (potrzeb, które mają na celu powrót do stanu równowagi, jak np. potrzeba zaspokojenia głodu czy potrzeba bezpieczeństwa) istotne są potrzeby wzrostu, wśród których najważniejsza jest samorealizacja (Arnold et al. 2005).

Odnosząc się do ujęcia motywacji w języku współczesnej psychologii, należy wskazać na kilka spraw. Po pierwsze, obecnie nie kwestionuje się pojęcia potrzeby, gdyż powszechnie przyjmuje się, że u człowieka biologicznie warunkowane popędy odgrywają znacznie mniej istotną rolę niż potrzeby, które kształtują się na bazie doświadczenia i mają charakter społeczny (tzn. mogą 
być realizowane w relacji z innymi ludźmi). Nie kwestionuje się także rozróżnienia na potrzeby typu homeostatycznego (potrzeby „braku”) oraz potrzeby wzrostu, choć, inaczej niż w modelu Maslowa, nie postrzega się tych drugich jako szczytowe osiągnięcia, co jest zilustrowane często przytaczaną wizją piramidy potrzeb. Przyjmuje się natomiast, że konkretne zachowanie może być motywowane oboma rodzajami potrzeb, a także że potrzeby mogą zmieniać się wraz z cza$\mathrm{sem}^{1}$. Brakuje także empirycznego potwierdzenia dla hipotezy o istnieniu hierarchii potrzeb, takiej, jak opisał to Maslow. Należy więc przyjąć, że piramida potrzeb to raczej użyteczna metafora, która przybliża osobom spoza kręgu psychologów system motywacji u człowieka, nie zaś „twarda wiedza” naukowa, która pomaga w strategicznych decyzjach w HR (por. Oleś 2003).

Na pewno odkryciem ostatnich trzech dziesięcioleci w psychologii jest rozwój i upowszechnienie się modelu poznawczego opisującego zachowanie człowieka, a także - na gruncie psychologii osobowości - badania nad postrzeganiem samego siebie, a więc psychologia ,ja”.

W ramach podejścia poznawczego podkreśla się, iż człowiek przetwarza aktywnie napływające informacje na temat rzeczywistości, porządkuje wiedzę w struktury poznawcze (schematy, skrypty), a wcześniej zebrana wiedza wpływa na odbiór napływających informacji. Tworząc mentalne reprezentacje rzeczywistości, człowiek kieruje się uproszczonymi regułami heurystycznymi, nie zaś systematycznymi algorytmami. Najważniejszym systemem wiedzy jest zaś system „Ja", a więc wiedza i sądy o nas samych (por. Tessre et al. 2004).

„Ja" to system schematów poznawczych, w których zawarte jest nasze doświadczenie, wiedza o nas samych, nasze relacje z innymi ludźmi, aspiracje i nakazy, które formułujemy dla samych siebie. Co ważne - z tym systemem związane są silne motywacje (potrzeby), które w niezwykle dużym stopniu modyfikują zachowanie człowieka. Te motywy to: potrzeba autoweryfikacji (utrzymania adekwatnego obrazu samych siebie) oraz potrzeba autowaloryzacji (utrzymania pozytywnego obrazu siebie). W zależności od charakterystyk indywidualnych oraz sytuacji, ludzie w różnym stopniu ujawniają obie te potrzeby: chcą wiedzieć, jak odbierane są ich działania, jakie są ich skutki i konsekwencje, ale równocześnie chcą, aby to, co robią, spotykało się z aprobatą ze strony innych i było pozytywnie oceniane. Ta odkrycie psychologii powinno być więc podstawą projektowania systemów motywacji w organizacjach.

Istotnym motywem związanym z „Ja” jest także potrzeba kontroli, sprawstwa oraz poczucia skuteczności własnych działań. $Z$ badań nad tymi potrzebami jasno wynika, że ludzie utrzymują osobiste zaangażowanie oraz kierują się w działaniu motywacją wewnętrzną tylko wtedy, gdy faktycznie mogą sprawować kontrolę nad zdarzeniami (ważnym elementem kontroli jest kontrola poznawcza, a więc rozumienie sensu zjawisk wraz z możliwością przewidywania przyszłym scenariuszy ich rozwoju), gdy to, co robią, umacnia i potwierdza ich obraz siebie (np. nie zaprzecza dotychczasowemu obrazowi siebie) i gdy pozostawia w nich poczucie, że są aktywnymi aktorami, nie zaś biernymi pionkami (por. Kofta, Szustrowa 2001). Sytuacje, kiedy człowiek pozbawiony jest kontroli bądź zmuszany do działań niezgodnych z obrazem własnego siebie (np. konfliktu wartości), prowadzą do bierności, wycofania zaangażowania, a nawet - w przy- 
padku braku poczucia kontroli - frustracji. Poczucie frustracji jest motorem działań zmierzających do przywrócenia poczucia kontroli, niekiedy nawet ze szkodą dla samej osoby (zachowania potocznie określane mianem „na złość mamie odmrożę sobie uszy”). Można przypuszczać, że właśnie niedostateczne poczucie kontroli wynikające z prowadzącego do niego sposobu zarządzania i organizacji pracy może być jedną z ważniejszych przyczyn zarówno bierności i braku inicjatywy wyrażanych przez pracowników, wycofania zaangażowania prowadzącego do wypalenia zawodowego, jak i wielu przejawów nielojalności i nieuczciwych zachowań pracowników.

Oprócz zwrócenia uwagi na potrzeby poznawczej oceny swoich działań (potrzeba kontroli, skutecznego działania), ważną rolę w mechanizmach zaangażowania osobistego odgrywa zgodność działania z własnymi osobistymi dążeniami oraz system wartości (por. Oleś 2003). Odpowiedzią HR na te potrzeby są np. praktyki planowania ścieżek karier, stosowania centrów rozwoju (development center), ale także praktyki mające na celu zrównoważenie potrzeb firmy z prywatnym życiem pracownika (np. elastyczne formy zatrudnienia, praca zdalna).

\section{| Podsumowanie}

W świetle przytoczonej literatury widać długą drogę, jaką przebyli teoretycy i praktycy zarządzania w podejściu do zasobów ludzkich. Od wykorzystania pracowników jako „ludzkich automatów", wykonujących pracę w zaprogramowany przez inżynierów i menedżerów sposób, po zdecentralizowane zbiorowości podejmujące na wpół autonomiczne decyzje i same projektujące procesy pracy, w zgodzie z wynegocjowanymi wspólnie z właścicielem celami przedsiębiorstwa, idea pracowników jako strategicznego zasobu przedsiębiorstwa rozwijała się z oporami przez 80 lat. W świetle wciąż rozwijających się technologii i coraz trudniejszych do przewidzenia wyzwań konieczne staje się dzisiaj łączenie wielu perspektyw badawczych w celu uzyskania lepszego wglądu w mechanizmy umożliwiające zwiększanie elastyczności działania firm i zwiększanie efektywności. Ważną perspektywą jest w tym wypadku perspektywa nauki o prawidłowościach rządzących ludzkim zachowaniem. Odpowiedni dobór, sposób organizacji i zarządzania może aktywizować potencjał jednostek, może także go blokować. Wiedza psychologiczna pozwala na wstępną ocenę skutków metod zarządzania na działanie jednostek i zespołów. Nowe narzędzia informatyczne pozwalające na zmniejszenie pracochłonności tradycyjnych zadań działów HR (Strohmeier, Kabst 2009; Ready et al. 2011) pozwalają spodziewać się silniejszego zwrotu w kierunku SHRM i zmniejszenia się oporu wyższej kadry menedżerskiej przed wykorzystaniem modeli rozwoju HR w strategicznych modelach działania organizacji (Becton, Schraeder 2009). Dotychczasowe postrzeganie działów HR jako realizatorów strategii dostarczających wykonawców do planowanych działań, ale niemających udziału w tworzeniu koncepcji rozwoju organizacji (Labedz, Lee 2011) jest w tej chwili coraz trudniejsze do obronienia, zarówno z perspektywy roli wiedzy i innowacji w zwiększaniu efektywności i umacnianiu pozycji rynkowej firmy, jak i z perspektywy roli pracowników w zapewnianiu firmie szybkości i elastyczności działania. 
B i b | i 0 g $r$ a $f$ i a

Arnold J., Silevester J., Patterson F., Robertson I., Cooper C., Burners B. (2005) Work Psychology. Harlow: Person Education.

Bamberger P., Meshoulam I. (2000) Human Resource Strategy. Formulation, Implementation and Impact. Thousand Oaks, CA.: Sage.

Barney J.B. (1991) Firm resources and sustained competitive advantage. Journal of Management, Vol. 17, s. 99-120.

Barney J.B. (2001) Resource-based theories of competitive advantage: A ten-year retrospective on the resource-based view. Journal of Management, Vol. 27, No. 6, s. 643-650.

Bartkowiak G. (2010) Psychologia w zarzq̨dzaniu. Nowe spojrzenie. Poznań: Wydawnictwo Uniwersytetu Ekonomicznego w Poznaniu.

Becton J.B., Schraeder M. (2009) Strategic Human Resources Management: Are We There Yet? Journal for Quality and Participation, Vol. 31, No. 4, s. 11-18.

Birdi K., Clegg C., Patterson M., Robinson A., Stride C.B., Wall T.D., Wood S.J. (2008) The Impact of Human Resource and Operational Management Practices on Company Productivity: a Longitudinal Study. Personnel Psychology, Vol. 61, No. 3, s. 467-501.

Carleton K. (2011) How to Motivate and Retain Knowledge Workers in Organizations : A Review of the Literature. International Journal of Management, Vol. 28, No. 2, s. 459-469.

Chadwick C., Dabu A. (2009) Human Resources, Human Resource Management, and the Competitive Advantage of Firms: Toward a More Comprehensive Model of Causal Linkages. Organization Science, Vol. 20, No. 1, s. 253-272.

Davenport T.H., Prusak L. (1998) Working Knowledge. How Organizations Manage what They Know. Boston: Harvard Business School Press.

Drucker P.F. (1999) Społeczeństwo pokapitalistyczne. Warszawa: Wydawnictwo Naukowe PWN.

Drucker P.F. (2004) Natchnienie i fart, czyli innowacja i przedsiębiorczość. Warszawa: Wydawnictwo Studio Emka.

Ferguson K.L., Reio T.G. (2010) Human resource management systems and firm performance. Journal of Management Development, Vol. 29, No. 5, s. 471-494.

Grossman M. (2006) An overview of knowledge management assessment approaches. Journal of American Academy of Business Cambridge, Vol. 8, No. 2, s. 242-247.

Hassan M., Hagen A., Daigs I. (2006) Strategic Human Resources as strategic weapon for enhancing labor productivity: empirical evidence. Academy of Strategic Management Journal, Vol. 5, s. 75-96.

Hendricks P. (2001) Many rivers to cross: from ICT to knowledge management systems. Journal of Information Technology, Vol. 16, No. 2, s. 52-72.

Jakubik M. (2007) Exploring the knowledge landscape: four emerging views of knowledge. Journal of Knowledge Management, Vol. 11, No. 4, s. 6-19.

Kofta M., Szustrowa T. (red.) (2001) Złudzenia, które pozwalaja żyć. Warszawa: Wydawnictwo Naukowe PWN.

Kożusznik B., Chrupały-Pniak M. (2010) Zastosowania psychologii w zarządzaniu. Katowice: Wydawnictwo UŚ.
Labedz C.S., Lee J. (2011) The mental models of HR professionals as strategic partners. Journal of Management $\&$ Organization, Vol. 17, No. 1, s. 56-76.

Markos S. (2010) Employee Engagement: The Key to Improving Performance. Journal of Business and Management, Vol. 5, No. 12, s. 89-97.

Mayo G.E. (1933) The Human Problems of an Industrial Civilization (wyd. 2003). Londyn: Routledge.

McHenry J.E., Strřnen F.H. (2008) The trickiness of IT enhanced competence management. Journal of Workplace Learning, Vol. 20, No. 2, s. 114-132.

Nonaka I. (1994) A Dynamic Theory of Organizational Knowledge Creation. Organization Science, Vol. 5, No. 1, s. 14-37.

Nonaka I., Takeushi H. (2000) Kreowanie wiedzy w organizacji. Warszawa: Wydawnictwo Poltext.

Oleś P.K. (2003) Wprowadzenie do psychologii osobowości. Warszawa: Wydawnictwo Naukowe Scholar.

Porter M.E. (2010) Strategia konkurencji. Metody analizy sektorów i konkurentów. Warszawa: MT Biznes.

Razmerita L., Kirchner K., Sudzina F. (2009) Personal knowledge management: The role of Web 2.0 tools for managing knowledge at individual and organisational levels. Online Information Review, Vol. 33, No. 6, s. 1021-1039.

Ready K.J., Johnson B., Astani M. (2011). Design and Implementation Issues in Integrating e-learning: Lessons Learned From a Fortune 1000 Firm. The Business Review, Vol. 18, No. 1, s. 1-8.

Senge P.M. (1998) Piąta Dyscyplina. Teoria i praktyka organizacji uczqcych się. Warszawa: Dom Wydawniczy ABC.

Serenko A., Bontis N., Booker L., Sadeddin K. (2010) A scientometric analysis of knowledge management and intellectual capital academic literature (1994-2008). Journal of Knowledge Management, Vol. 14, No. 1, s. 3-23.

Stewart T.A. (1991, June 3) Brainstorming. Fortune, s. 44-60.

Strohmeier S., Kabst R. (2009) Organizational adoption of e-HRM in Europe: An empirical exploration of major adoption factors. Journal of Managerial Psychology, Vol. 24, No. 6, s. $482-501$.

Sun P. (2010) Five critical knowledge management organizational themes. Journal of Knowledge Management, Vol. 14, No. 4, s. 507-523.

Tesser A., Felson R.B., Suls J.M. (red.) (2004) Ja i tożsamość. Gdańsk: Gdańskie Wydawnictwo Psychologiczne.

Thompson P., Warhurst C., Callaghan G. (2001) Ignorant theory and knowledgeable workers: Interrogating the connections between knowledge, skills and services. The Journal of Management Studies, Vol. 38, No. 7, s. 923-942.

Woolley A.W., Chabris C.F., Pentland A., Hashmi N., Malone T.W. (2010) Evidence for a collective intelligence factor in the performance of human groups. Science, Vol. 330, No. 6004, s. 686-688.

Wright P.M., Dyer L.D., Boudreau J.M., Milkovich G.T. (red.) (1999) Strategic Human Resources Management in the TwentyFirst Century. Stanford, CT: JAI Press. 